Vol. 1, No. 1, 2019

https://doi.org/10.23939/jtbp2019.01.017

Petro Reznik, Ludmila Gaponova, Sergey Grebenchuk, Roman Koreniev

\title{
PROGRESSIVE COLLAPSE OF THE SPECIAL-TYPE ARCH SYSTEMS: MODELING ALGORITHM
}

\author{
Department of Building Structures, \\ O. M. Beketov National University of Municipal Economy in Kharkiv, \\ r.v.korr@gmail.com
}

(C) Reznik Petro, Gaponova Ludmila, Grebenchuk Sergey, Koreniev Roman, 2019

This paper is devoted to the frameless coverings - special-type arch coverings extended to territories of Ukraine. This type of covering is essentially folded open type cylindrical ribbed shells that are based on an arched structural element - the thin-walled, cold-deformed profile. Based on accepted hypotheses and implementing structural nonlinearity and illustrating the possibility of progressive collapse, the algorithm of creating finite-element models of these coverings was constructed. During the research, to the verification created algorithm, the full-scale experiment was done. The stress-strain state of a block of the original structure and numerical model were analyzed. The components of the stressstrain state obtained in the research are presented in the form of a mosaic of the vertical deflections. Comparison of the calculated deflections and the experimental ones are shown. The qualitative congruence of the results proves the adequacy of the algorithm.

Key words: special-type arch coverings, open-type cylindrical compound shell, buckling, progressive collapse

\section{Introduction}

A special-type arch coverings (Fig. 1) allow to erect buildings and structures for various purposes in the shortest possible time. In essence, this type of coverings is folded open-type cylindrical ribbed shells, which are based on an arched structural element - a thin-walled, cold-deformed steel profile.
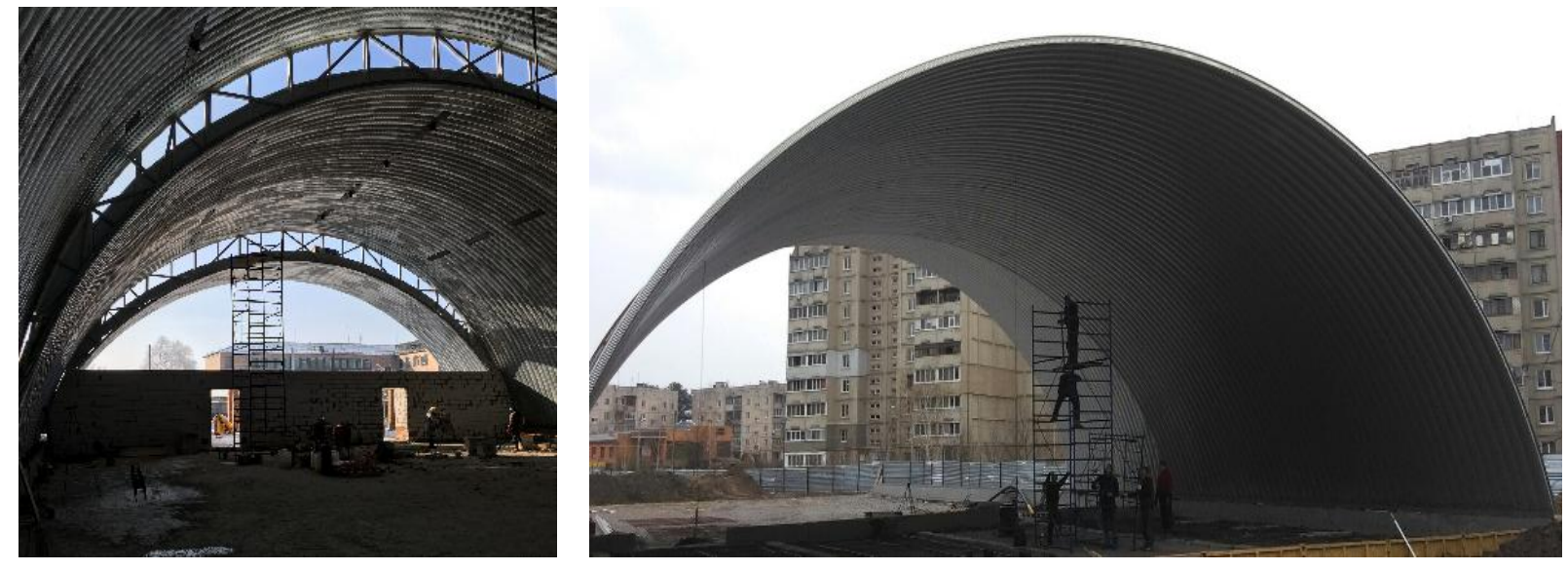

Fig. 1. An example of a special-type arch covering erection

Production of structural elements - the arch profiles is carried out directly at the construction site. Because of this, and depending on

The distance between the supports of the arched elements varies in the range from 6 to $30 \mathrm{~m}$ depends on loads and constructive solutions [Vediakov et al., 2009]. Production is made of coiled steel with a thickness of 0.7 to $1.2 \mathrm{~mm}$, depending on the designed span. Individual structural elements, 3 or 5 pieces, 
are combined into sections by automatic rolling. After the installation in the design position, these sections are also combined with the help of a roller joint. Thus, the shell is typing to the designed length [Armenskyi et al., 2007]. After analyzing the data on the researched arch coverings, it can be noted that the features of the modeling of frameless coatings are considered in researches [Giabinsky et al., 2012], [Armenskyi et al., 2009]. Frameless coatings were also studied abroad. In the United States, large-scale experiments were conducted to research the actual operation of arched structures from a U-shaped section profile. The research was conducted by Steven Sweeney, Demetre Briassoulis and Anthony Kao. Both separate sections of profiles for cantilever and transverse bending, as well as natural fragments of coatings, were tested. According to the test results, the stiffness characteristics of the profiles were determined, as well as the ultimate load of general and local buckling. The results of this research were used to create guidelines for the design of frameless structures, which was developed by M.1.C. Industries, Inc [Structural analysis software for the automatic building machine: user guide, 2009]. The most comprehensive review of researches conducted abroad is given in the [Wei-Wen Yu and Roger A. LaBoube, 2009] book. The research [D. Dubina et al., 2012], discusses the main assumptions adopted in the development of American and European regulatory documents on the calculation of structures under consideration [AISI S100-2012], [EN 1993-1-3:2006].

Not only the structures themselves but also anomalies and collapses that occur during their operation are of considerable scientific interest. The article [Kyznetsov et al., 2011] discusses the causes of the collapse of the researching types of structures. The most frequent causes of collapses appearing in expert opinions regarding an accident include:

- project errors;

- technological defects;

- violation of the rules of maintenance.
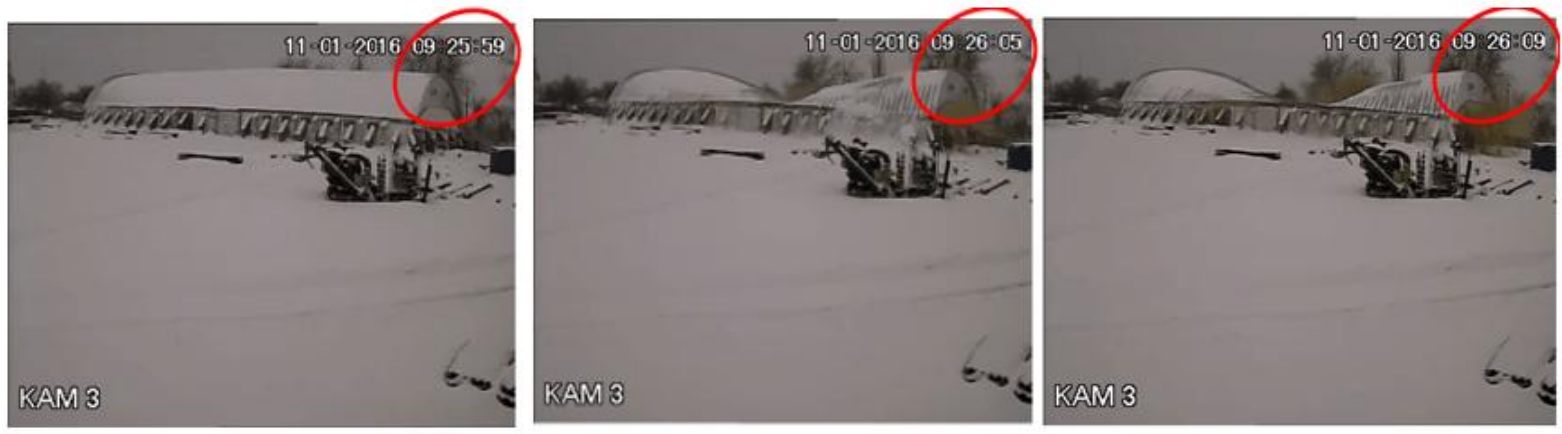

Fig. 2. Progressive collapse of a special-type arch structure

Fig. 2 shows the frame-by-frame fixation from video surveillance cameras, the process of collapse of the arched structure. Analyzing the speed and nature of the collapse, it can be concluded that there is a "progressive" or "avalanche-like" collapse, in other words, there is a buckling of these cylindrical ribbed steel shells. The emergence of the theme of "progressive" collapse is associated with a number of tragic accidents [Crowder, 2005] for which there was a disproportionality factor between the cause (emergency accident) and the magnitude of the final damage, which is observed in the analysis of the collapse of special type shells [Crowder, 2005].

According to the above determined the main aim of the current research as creating an algorithm of design special-type arch coverings that can show the possibility of progressive collapse and implement structural nonlinearity.

\section{Hypotheses and assumptions}

Consideration of qualitative and quantitative results was carried out in the PC "Lira" (license number 1/6258), which is based on the finite element method [Gorodetskiy et al., 2003]. Usually, regulatory 
documents prescribing the provision of resistance to progressive collapse in case of emergency exposure usually imply a nonlinear finite element analysis, which leads to the need for determination the criterion of exhaustive bearing capacity of a structure. Using the theorem [Shmukler et al., 2008]. "The potential energy of the system's deformation $(U u)$ when one bond is applied is less or at least not more than the energy of the original system" was made the consequence that With the avalanche-like elimination of bonds, as a result of the appearance of plastical hinges, to the ultimate state, when the system turns into a mechanism, the potential deformation energy increases and reaches the upper limit, that is, $U u=$ supremum $U$.

The algorithm, in this case, involves the determination of the internal parameters of the system, as a result of the consistent construction of the energy portrait of the system. When constructing algorithms for the design of structures, the structure-forming fundamental value $e_{n}$-a measure of the material viscosity or the ultimate strain energy density. It is determined by the work expended on the deformation of the sample up to its destruction, per unit volume (and the measured area of the stress-strain indicator diagram $(« \sigma-\varepsilon »)$. According to the above, if in an individual volume, for example, the final element, the strain energy density is greater than the ultimate strain energy density, this volume would be destroyed.

\section{Structure of the method}

To build a finite element model of enhanced correctness, with the goal of implementing the previously described principles, and the possibility of reflecting progressive collapse, it was assumed to develop a special algorithm. In general terms, this procedure is presented on the flowchart (Fig. 3).

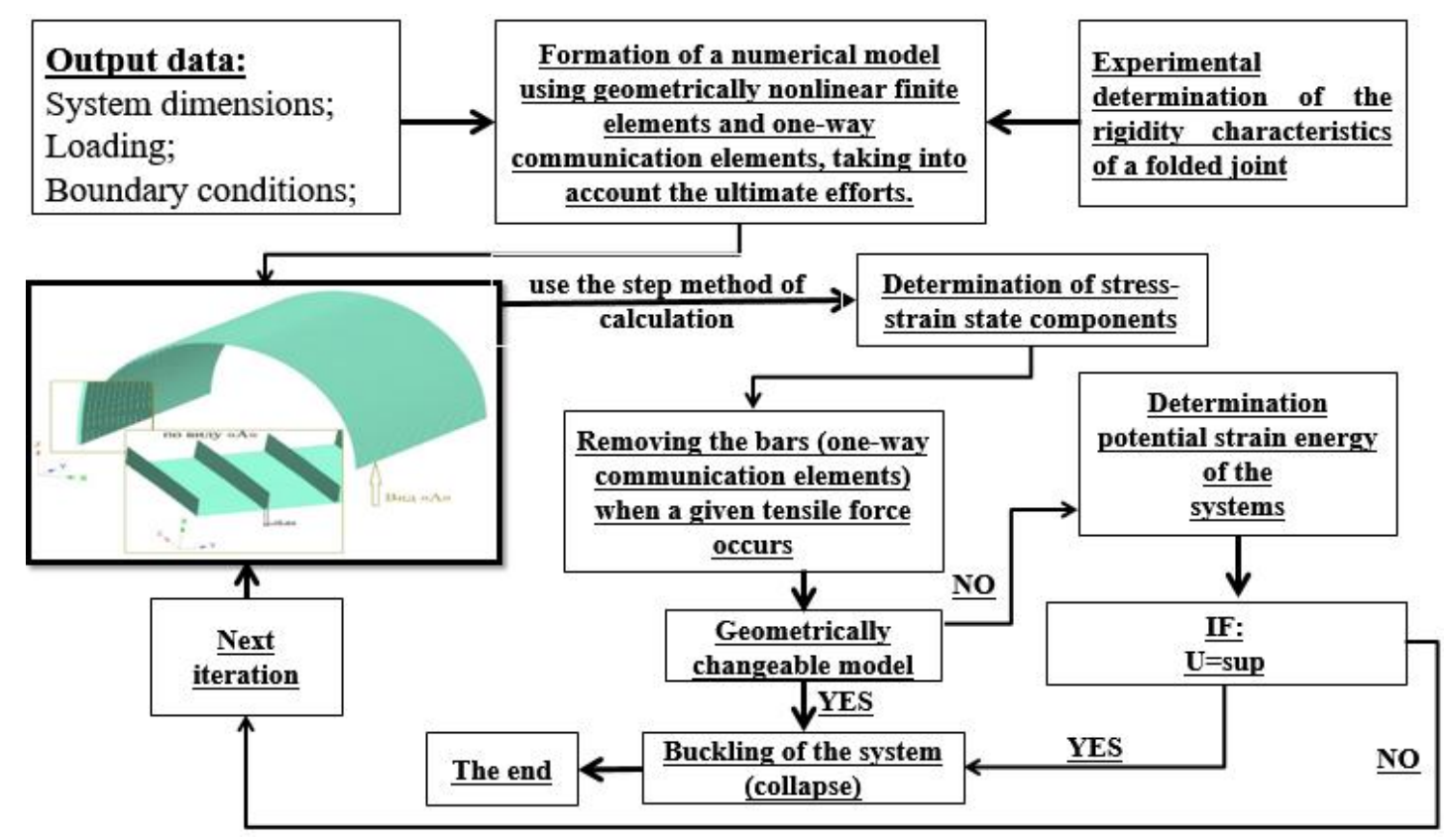

Fig. 3. The flowchart of the research stress-strain state algorithm of the arch-type system, taking into account the deformed scheme and probability of progressive collapse

During operation of this algorithm, the use of nonlinear finite elements is proposed. First of all, it is the use of a geometrically nonlinear finite element of the shell (which allows, at each step of loading, when building a stiffness matrix, to take into account all efforts and geometry changes. At the same time, the rigidity matrix is formed in the coordinate system of the "new position" direction cosines, efforts are calculated in the coordinate system of the "new position".

To reflect the rigidity of the folded connection of arched steel profiles, it is performed by modeling this structural non-linearity, using a two-node final element of elastic connection, designed to simulate a node that perceives either tension or compression. 


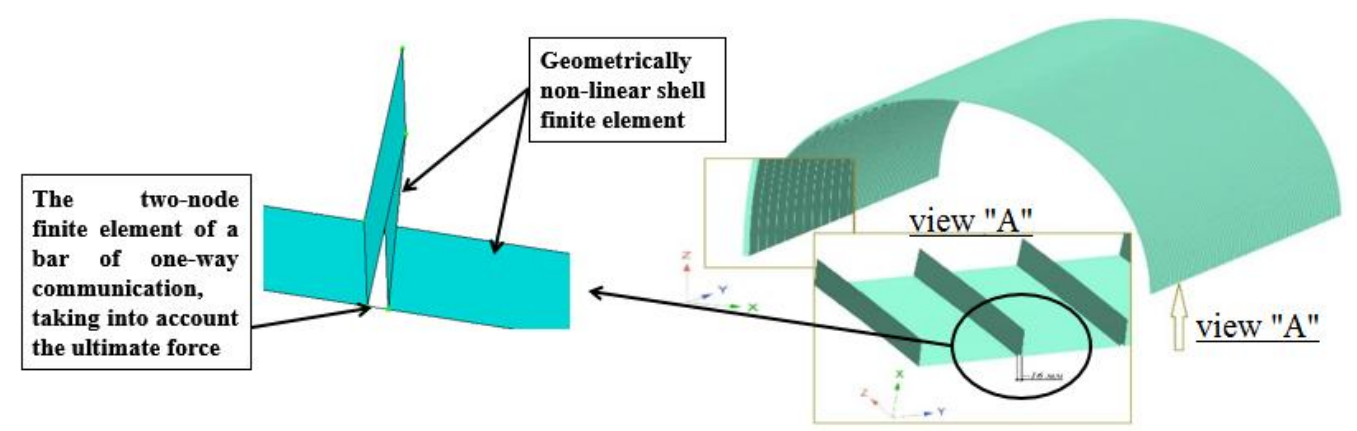

Fig. 4. An example of the finite element model of the special-type arch system, according to the created algorithm

For non-linear problems, the step method is used with automatic step selection. if at any of the iterations (step) the effort in the connection has become more (less) specified, then the connection at the subsequent iteration is turned off from work.

The algorithm can be implemented using the "Lira" (license number 1/6258) software package. Some other calculations and modeling were created by using open-access-version of "Autodesk Inventor" and "ANSYS", on the way as shown in research [Kalmykov et al., 2008]. Figure 4 shows an example of the finite element model of the special-type arch system, according to the created algorithm.

\section{Verification of the proposed method}

The verification of the proposed algorithm was carried out in the course of the experiment, involving the research of the actual deformed state of the special-type arch covering and its comparison with the computational model.

The researched block of covering is close to a square, in a plan, cylindrical composite coating shell. Block dimensions: span between side elements 22 m., Block length 15.6 m., Lifting arm 8.37 m., Radius of the cylindrical shell $11.585 \mathrm{~m}$. The thickness of the steel element was $1.2 \mathrm{~mm}$.
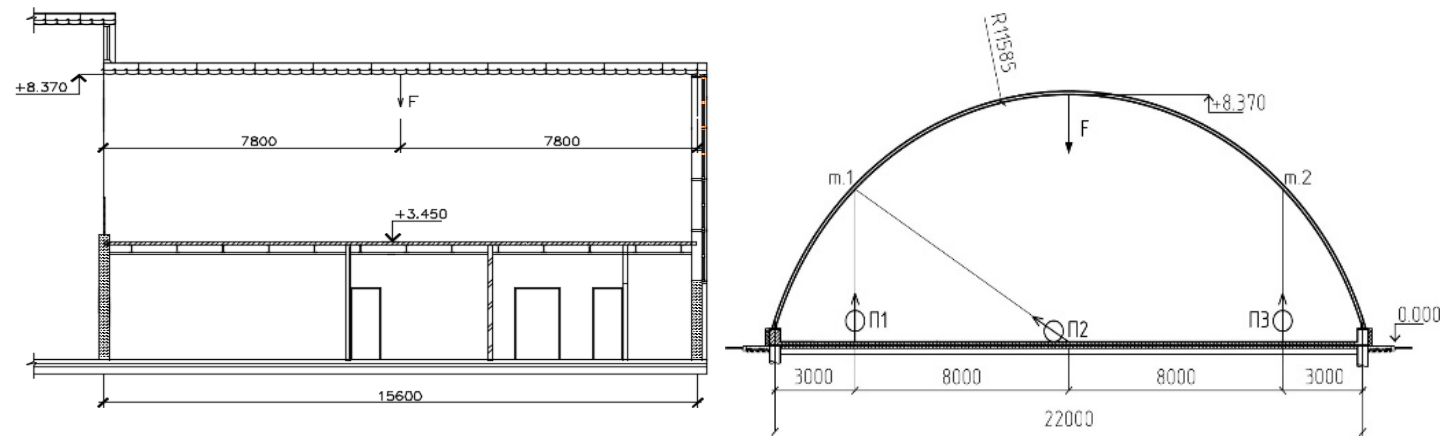

Fig. 5. The loading and measurement schemes.

$F$-loading; “ $n 1, n 2, n 3$ - “6PAO” deflectometers; $m 1, m 2$ - tracked points

According to the above-described algorithm, a finite element model of the special-type arch covering was constructed and calculated. As an example of the calculation result fig. 6 shows mosaic of vertical deflections under the loading equal $200 \mathrm{~kg}$.

The loading scheme is shown on the Fig. 5. The registration of movements was carried out by the "6PAO" system of deflection, the layout of measuring instruments, as well as the points at which the movement was monitored are indicated (Fig. 5). According to the loading system, the load was applied iteratively at 20 kilograms at each iteration (the weight of one calibrated load). The maximum load applied was $200 \mathrm{~kg}$.

According to the above-described algorithm, a finite element model of the special-type arch covering was constructed and calculated. As an example of the calculation result fig. 6 shows mosaic of vertical deflections (mm) under the loading equal $200 \mathrm{~kg}$. 


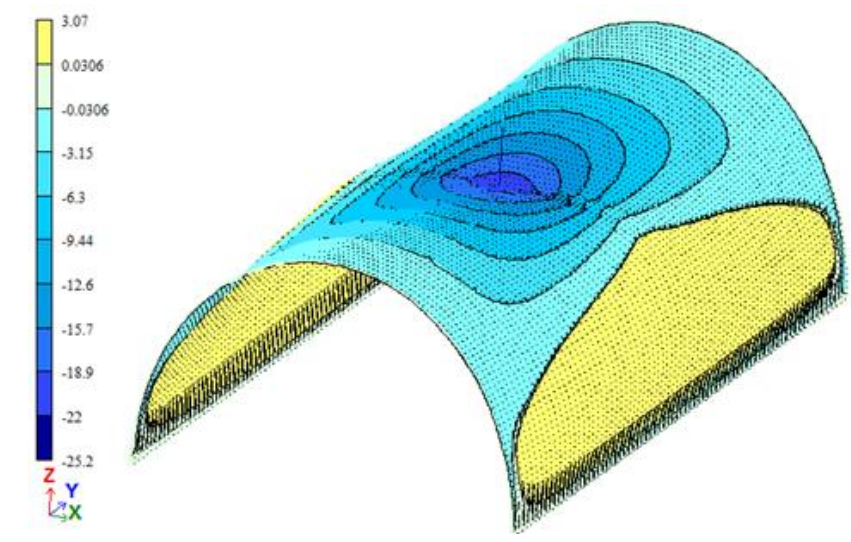

Fig. 6. Mosaic of vertical displacement under loading $200 \mathrm{~kg}$. Deformed scheme (on a scale)

A comparison was made of the calculated and actual displacements of the control points, depending on the actual loading. These comparisons are presented as a graph, relative to the calculated values in Fig. 7.

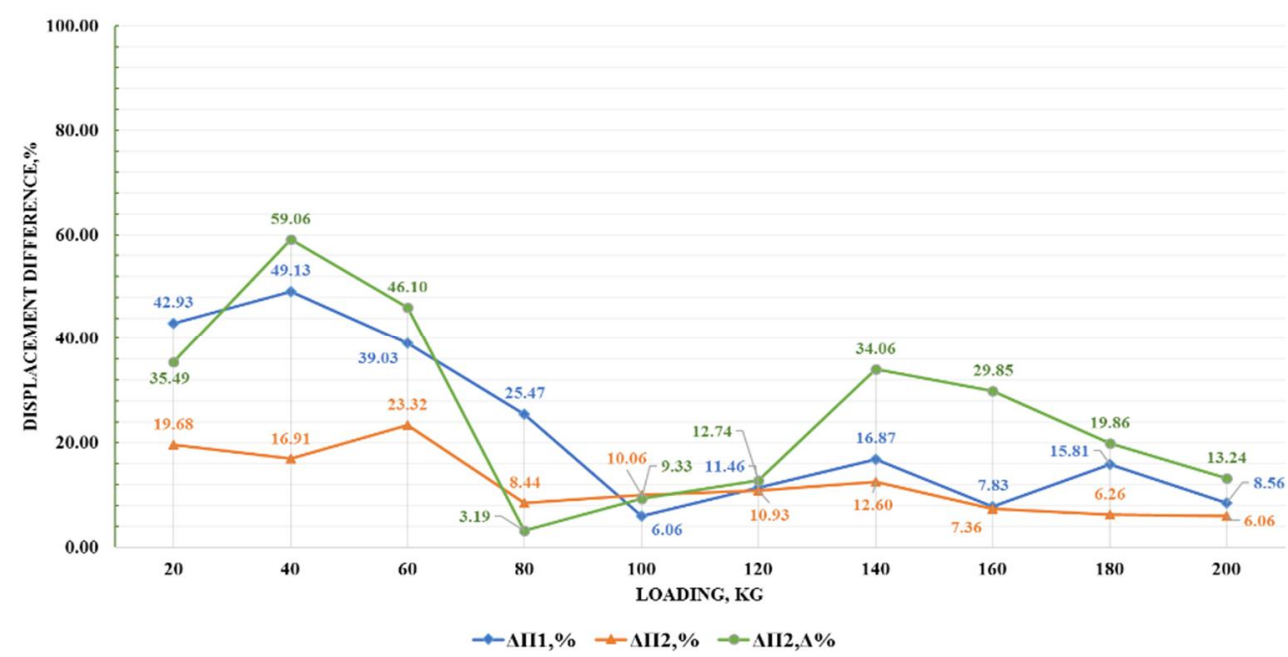

Fig. 7. Comparative analysis of the values of displacements (experimental relative to the calculated)

\section{Conclusions and practical significance}

Analyzing the obtained results, it should be noted that exceeding the $15 \%$ threshold of the difference of the calculated deflections and the experimental ones is due to the virtual geometric imperfections of the structural arch elements, which in this case positively affected the stiffness characteristics of the system design as a whole. In turn, the qualitative congruence of the results proves the adequacy of the algorithm of the creation computational model and the correctness of the laid down principles, also it gives the right to consider the verification successful. The practical significance of the method is determined by a logically composed and justified procedure for modeling and calculating operations, which allows analyzing the stress-strain state and the possibility of a progressive collapse of the special-type arch coverings that wasn't able to do using regular algorithms proposed for this types structures.

\section{References:}

Vedyakov I. I., Solovev D. V., Armenskiy M. Y. (2007). Novyie tipyi beskarkasnyih zdaniy i perspektivyi ih razvitiya. Promyishlennoe i grazhdanskoe stroitelstvo. Vol. 10, 27-29. 
Armenskiy M. Y., Vedyakov I. I., Eremeev P. G. (2007). Issledovaniya i proektirovanie beskarkasnyih arochnyih svodov iz holodnognutyih stalnyih tonkolistovyih profiley. Promyishlennoe i grazhdanskoe stroitelstvo. Vol. 3, 16-18.

Zhabinskiy A. N., Starovoytov A. F. (2012). Modelirovanie arochnyih pokryitiy iz tonkostennyih holodnognutyih profiley.Tehnicheskoe normirovanie, standartizatsiya i sertifikatsiya v stroitelstve. Vol. 4, $20-21$.

Armenskiy M. Y. (2009). Opyit ispolzovaniya chislennyih metodov v issledovaniyah geometricheskih harakteristik tonkostennyih profiley. Promyishlennoe i grazhdanskoe stroitelstvo. Vol. 6, 23-26.

M. I. C. Industries, Inc., (2009). Structural analysis software for the automatic building machine: user guide. Reston:. -75 pp.

Wei-Wen Yu, Roger A. LaBoube (2010). Cold-formed steel Design. John Wiley \& Sons, 489.

Dubina, D., Ungureanu V., Landolfo R. (2012). Design of cold-formed steel structures: Eurocode 3: Design of steel structures. Part 1-3 - Design of cold-formed steel structures, First Edition. Ernst \& Sohn, 676 pp.

North American Specification for the Design of ColdFormed Steel Structural Members, AISI S100-2012 (2012). Edition. American Iron and Steel Institute (AISI), Washington, DC.

Eurocode 3: Design of steel structures - Part 1-3: General rules - Supplementary rules for cold-formed members and sheeting (2005), EN 1993-1-3:2006. CEN, Brussels.

Kuznetsov I. L., Isaev A. V., Gimranov L. R. (2011). Prichinyi obrusheniya beskarkasnogo arochnogo sooruzheniya proletom 30 m. Izvestiya KazGASU. Vol. 4. 166-170.

Crowder B. (2005) Definition of progressive collapse. - Navfac - 10 p.

Crowder B. (2005) Devil in details. - Navfac. - 12 p.

Gorodetskiy A. S., Shmukler V. S., Bondarev A. V. (2003). Informatsionnyie tehnologii raschyota i proektirovaniya stroitelnyih konstruktsiy. [Information technology calculation and design of building structures]. NTU "HPI", Harkov, 889.

Shmukler V., Klimov Yu., Burak N. (2008) Karkasnyye sistemy oblegchennogo tipa. Kharkiv, Zolotyie stranitsy.

Kalmykov, O., Gaponova, L., Reznik, P., Grebenchuk, S. (2017). Use of information technologies for energetic portrait construction of cylindrical reinforced concrete shells. MATEC Web of Conferences, 116, doi: 10.1051/matecconf/201711602018.

П. Резнік, Л. Гапонова, С. Гребінчук, Р. Коренєв Харківський національний університет міського господарства ім. О. М. Бекетова, кафедра будівельних конструкцій

\section{ПРОГРЕСУЮЧЕ РУЙНУВАННЯ АРКОВИХ СИСТЕМ СПЕЦАЛЬНОГО ТИПУ: СПОСІБ МОДЕЛЮВАННЯ}

(С Резнік П., Гапонова Л., Гребінчук С., Коренєв Р., 2019

Розглянуто безкаркасні покриття - аркові покриття особливого типу, використання яких останнім часом поширюється на території України. Ці покриття, за змістом, є складеними циліндричними ребристими оболонками відкритого типу, що складаються з аркових конструктивних елементів - тонкостінного холоднодеформованого металевого профіля.

На основі прийнятих гіпотез та втілення засад конструкційної нелінійності побудовано скінченноелементні моделі зазначених покриттів, а також розроблено та запропоновано спосіб запобігання прогресуючому руйнуванню. Створено скінченноелементні моделі, що реалізують зазначені конструктивні заходи запобігання прогресу руйнування. Під час проведеного дослідження проаналізовано напружено-деформований стан оригінальних та модернізованих конструкцій покриттів. Визначено відповідні форми втрати стійкості та параметра запасу стійкості (критичний параметр стійкості). Практичне значення методу визначається логічно складеною та обгрунтованою процедурою моделювання операцій, що дає змогу проаналізувати стан напруженості та можливість прогресивного обвалення аркових покриттів спеціального типу.

Отримані під час дослідження компоненти напружено-деформованого стану подано у вигляді мозаїк ізополів основних розтягуючих напружень $\sigma_{1}$ та основних стискаючих напружень $\sigma_{3}$, а також у вигляді ізополів вертикальних переміщень та коефіцієнта запасу стійкості у вигляді відносної діаграми для кожної зі скінченноелементних моделей.

Ключові слова: аркове покриття особливого типу, циліндричні ребристі оболонки відкритого типу; вигин; прогресуюче обвалення. 